\title{
E-COMMERCE IN INDIA: OPPORTUNITIES AND CHALLENGES
}

\author{
DR. RAMANDEEP SAINI ${ }^{1} \&$ INDUBALA ${ }^{2}$ \\ ${ }^{1}$ Director -Principal, Business Management, Chandigarh Group of Colleges, Landran, Mohali \\ ${ }^{2}$ Research Scholar (Management Department), IK Gujral Punjab Technical University, Kapurthala
}

\begin{abstract}
Electronic commerce is commonly written as E-commerce. It is the transaction of buying and selling products online. ECommerce makes use of several technologies such aselectronic fund transfer, online transaction, electronic data interchange and inventory management system. E-Commerce is growing at a faster pace as it strengthens their websites offering consumer security and privacy. The E-Commerce industry seems to show faster growth in India in the last few years. Customers are becoming more aware and internet users are increasing day by day. This paper tries to study the present scenario of E-commerce in India, growth and opportunity booster factors towards the development of Ecommerce and barriers for E-commerce in India.
\end{abstract}

KEYWORDS: E-Commerce, Customers, Scenario, Opportunity and Barriers

Received: Jun 08, 2020; Accepted: Jun 28, 2020; Published: Aug 31, 2020; Paper Id.: IJMPERDJUN2020989

\section{INTRODUCTION}

E-commerce interacts with goods and services with the help of electronic media and the internet. It involves the transaction with the usage of internet and information technology like electronic data interchange (EDI). It consists of a website that provides services directly from its portal to the customers. Payment is done with the use of a digital shopping cart system where credit card, debit card or electronic fund transfer payments are used. Different parties interact electronically involving a wide range of suppliers. Day by day, technology gets advanced, there is an increase in consumerism and e-commerce reaches its peak in online transaction. As the number of internet users is increasing and easy way to access from mobile devices helps to increase the confidence of the customers to buy online products. The increase in the literacy rate and the use of internet facility on the cheapest cell phones helps in the substantial growth of e-commerce. Telecommunication technology brings so many changes in the way of shopping and communication. It makes a lot of changes in access to information and the way to buy or sell the product. The growth of e-commerce provides a platform for different business holders and also beneficial for the upliftment of education as well for the academician's growth. All these factors seem to highlight the vast scope of ecommerce in India. There is multi-product e-commerce as well as single product e-commerce. Some websites include almost all categories of goods and services whereas some portals provide the product and services consist of a single category such as industries of real estate, travel and tourism.

\section{Objectives}

- To highlights the present scenario of E-Commerce in India.

- To study the growth and opportunity booster factors towards the development of E-commerce. 
- $\quad$ To examine the barriers of E-commerce in India.

\section{Research Methodology}

The present paper uses the secondary source of information. The present research is descriptive as well as theoretical in nature. Secondary data is collected from various journals, books, articles, research papers and websites.

\section{REVIEW OF LITERATURE}

- Mitra,2013 in one of his study states that e-commerce brings a big change in the business. It changes the way of purchasing and selling of the product. New methods have developed. The geographical distance is no longer restricted in maintaining the business relationship. The $3 \mathrm{G}$ and $4 \mathrm{G}$ network has contributed greatly to the overall development of the E-commerce industry.

- Madhukar,2015 in one of his paper states that e-commerce helps to reduce the gap between the owner of the product and consumer. E-commerce is rapidly growing in India but due to the gap in maintaining proper security, some problems are faced by society.

- Saxena, 2015 in her paper highlights the importance of e-commerce. E-commerce helps a lot in updating the Indian economy. It acts as a great supporter of the development of small and medium enterprises to uplift their transaction. E-commerce faces many barriers such as lack of proper laws and lack of education in computer.

- Ramchandani, 2016 in one of papers estimates that e-commerce sales will reach $1.4 \%$ in 2018 . E-commerce has a great impact on physical retailers, especially small retailers. But physical retailers still have a good position in the Indian market as the people generally want to touch and inspect the product before making any purchase. International e- retailers are an alert for domestic ones.

- Meenakaand Seethal, (2018) in one of the paper discuss the importance of smartphones and the internet facility which brings revolutionary changes in E-Commerce. E-commerce does not involve any intermediaries. Ecommerce provides the facility sitting at home. Customers get a chance to select from different products. Payment procedure is so easy that the customer can use a debit card, credit card, e-wallet, or e-cash. E-commerce offers huge benefits to its customer.

\section{Present Scenario of E-Commerce in India}

The E-Commerce industry in India is growing rapidly and it is expected to get the second position in the E-commerce market in the world by 2034. E-commerce in India started in the late nineties under business to business users(B2B). The business to consumer(B2C) interaction is started in 1996 with the matrimonial portals. The speed of the internet and its cost is the major barrier for the growth at that time. Rediff.com was the first website used in India and the site was remaining busy most of the time. So many sites have shifted towards E-commerce.Today, E-commerce is growing at a much faster rate.There are a multi-product as well as single product E-Commerce sites. Today, every customer is fully aware of these transactions. As time passes the internet users have increased day by day. Internet subscriber has reached at 665.31 million by June 2019. It is estimated that internet users are increasing every month by approximately 10 million. These users are supporting the e-commerce industry in India which is the highest rate in the world. It is expected that the online shopping customer to reach 220 million by 2025. Further, India has started the 'Digital India' campaign and its aim 
to create a trillion-dollar online economy by 2025. Several key players are contributing to the e-commerce in India that is flipcart.com, amazon, snapdeal, nykaa.com, myntra.com, jabong.com, Paytm mall and shopclues.com. Figure 1.1 below shows the internet penetration in India(\%) and figure 2.2 below shows the E-Commerce industry in India (the US \$ billion).

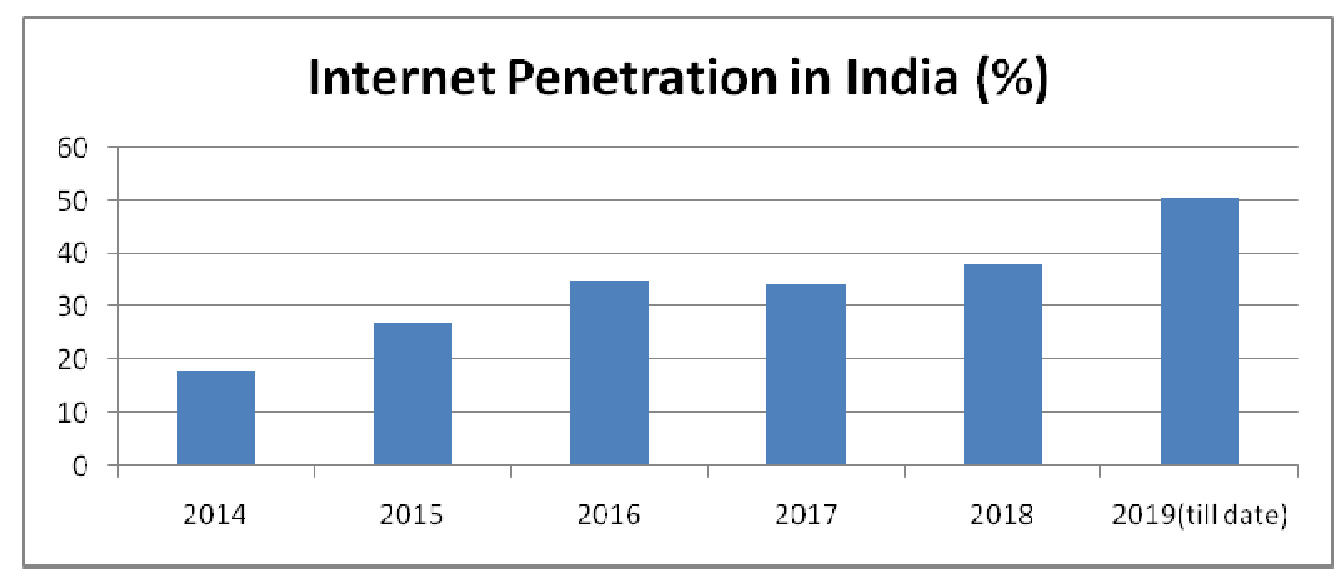

Source: https://www.ibef.org/download/E-Commerce-December-2019.pdf

Figure 1

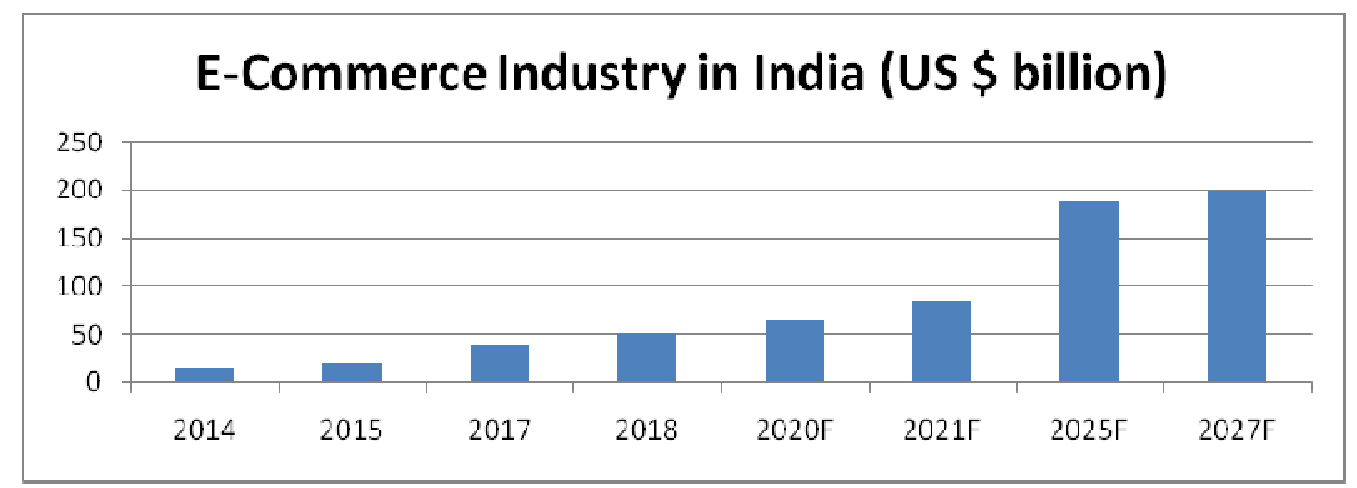

Source: https://www.ibef.org/download/E-Commerce-December-2019.pdf

Figure 2

\section{Growth and Opportunity Booster Factors Towards the Development of E-Commerce}

- Awareness of using the internet is increased and more people are motivated towards the use of e-commerce. When the talk is about the seller, buyers, customers or investors, the popularity for e-commerce is getting increased.

- As day by day, digital literacy is getting increased, more and more investment in e-commerce firms is getting expanded. The new dealers get the opportunity to start up their business and new ideas are welcomed to end up the old functions.

- In India, changes in FDI policy favor a lot. 100 percent FDI is allowed in business to business E-commerce which favors a lot for its development.

- In October 2019, an effort is being done to update the online payment system in banks. Memorandum of understanding is undertaken with the union bank of India for the cashless, paperless and transparent payment system. 
- Many of the sites help to choose the product by providing a personalized experience to them. All these depend on the location, choices, their likeness, websites they visit. This step is very beneficial to know the customer choices and fulfills their demand accordingly. In such an effort, one of the best examples is of myntra. It has started a voice search technology and likewise many of the sites have adopted it. Another example is of phonepe which introduced a stores tab and merchant tab separately.

- Different strategies adopted by various key players. For example, Amazon is rapidly increasing the work in the streaming of video, assistant in a voice as in Alexa and various food retail services. Then another example is Flipkart who introduced a payment procedure that is payzippy and self-supply chain firm Ekart. One of the best examples isto introduce e-Wallet services as Amazon's Pay Balance. Paytm is doing great efforts and launched a bank - Paytm Payments Bank. Paytm bank holds the first position in India to allow the transaction with zero charges ononline transactions, no minimum balance requirement and a free virtual debit card.

- Indian key players are well prepared for huge investments in e-commerce. As in September 2019, phonepe introduce 'Switch' to give help to the customers operating several other merchant apps.

- Different measures are taken to attract the customer. As in 2014, Flipkart had introduced service based on a premium subscription for the benefit of the customer. Likewise in 2018, swiggy, zomato and myntra introduced several models to attract customers.

- Several delivery players such as swiggy, dunzo,zomato etc make their customers satisfied by delivering to their customers in 30 minutes. Similarly, nowadays the amazon is trying to improve their logistic operation and to deliver the product same-day or within two days.

- Various segments contribute differently to E-commerce. Electronics and apparel have contributed tremendously to online retailing in India. It is expected that the non-electronics items will take greater share by 2025.

\section{Barriers of E-Commerce in India}

- Low internet penetration: As compared to different countries such as the USA, France, UK and many more, internet penetration is low in India. However, we are having 4G internet services and preparing to have 5G internet facilities. But the quality of connectivity is slow in some regions, especially in rural areas. The good news is that this problem is disappearing in India. In the coming years, the connectivity problems will also disappear from the list of challenges in India.

- Security issues: Customer feels insecure in purchasing order online. Customers have doubts about the integrity of the dealers. There is always some risk of hacking. Online payment creates a risk in the mind of customers. They feel insecure and risky as to maintain privacy is also a major concern for the customer. In India, the major problem is that most of the people have no trust in online transactions. It is found that the fraud cases registered on the national consumer helpline number are increasing day by day.According to the data, online fraud cases increases nearly six times since March 2017. Therefore, the dealers have to ensure their customer full protection in using e-commerce sites. SSL certificates and following the standards such as PCI DSS for protecting the information are the most important steps.

- Return the product: E-commerce is expanding at its peak in India. There are lots of first-time buyers. As the 
product delivered, they regret their order and prepare to return the goods. Sometimes, the customer uses the product and then decides to return it. This is a major problem in India. E-commerce retailers are facing this major challenge which can be extremely expensive for them especially in the cross border areas.

- Timely delivery:Delivery of the product at the proper time is the main concern for the dealer. In India, most of the population lives in remote places. Firstly to make the consumers aware of these products is the main task. Then, the delivery of the product is to be on time. The companies have to invest in the establishment of a nearby warehouse and to appoint some suppliers to ensure the timely delivery of the product.

- Payment mode: In India, most of the customers prefercash on delivery. But the dealer finds it very difficult to handle. This mode results in several expenses. Sometimes Courier Company takes so many days to return the cash collected from the customer. In case, the customer returns the product, the expenses for two way courier charges have to bear by the company.

- Tax structure: Tax structure is also one of the reasons for the lesser growth of e-commerce as compared to other countries such as the USA and the UK. Various types of taxes that create a hindrance to the working of the business. Some states have strict rules for e-commerce. To upgrade the tax structure, the government has implemented the GST act, which comes with significant benefits. The restrictions on cross utilization of credits get removed and it has shown significant benefits in e-commerce.

- Maintenance of customer: E-commerce is a kind of transaction in which the maintenance of the previous customer is most important. The dealer has to maintain a proper check on the coming of new products in the market, its variety, its type as well as a range of it. There should always be the availability of bulk stocksfor the upcoming demand. The demand for a product can be increased or decreased depending upon the situation. The dealer has to get ready for flexible situations. This part is difficult as well as complicated to handle and it requires the proper attention of the dealer.

- Trust maintenance: One of the biggest challenges for the dealer is to maintain customer trust. According to the national retail federation survey, approximately $30.2 \%$ of the frauds occur in online-only sales. Nowadays, consumers become so aware that they read both the positive as well as negative reviews. Positive feedback creates a doubt in the mind of the customer. But more negative views divert the mind for not purchasing the product. In one of the studies, $68 \%$ of consumers want to hear both the bad as well as good news.Therefore, the dealer has to study deeply the psychological state of the customer and target them accordingly.

\section{CONCLUSIONS}

The future of E-commerce is dependent on the various factors responsible for the development of E-commerce. There are some of the barriers which need to be focused and removed for the growth of E-commerce. In this competitive era, the focus of the businesses should be always to fulfill the demand of the consumers. Consumer's needs and demands are getting changed as time passes. E-Commerce dealer needs to know the changing pattern of the consumers as it will prove to be effective for business success. There is no doubt that E-commerce is attaining its highest growth as the technology is getting updated day by day. However, e-commerce is having certain disadvantages too which can be avoided by careful scrutinization. The need is to adopt the correct method and practices so that e-commerce can attain a maximum height of success. India is developing faster in the E-commerce industry to become a digitally empowered society. The effort for e- 
governance, the discoveries of smartphones, rapid increase in the usage of internet access and hump in the digital payments are moving the country towards the trillion -dollar digitalization by 2025. Digitalization act as a catalyst for economic growth and rapidly moving towards the growth story.

\section{REFERENCES}

1. Menaka, B., \& Seethal, K. (2018). Recent Trends in E-Commerce. Shanlax International Journal of Commerce, 6(S1), 40-44.

2. Mitra, A. (2013). E-commerce in India-A Review. International journal of marketing, financial services \& management research, 2(2), 126132

3. Ramchandani, D. P. H. (2016). Growth of e-commerce in India and its impact on the Indian economy. Abhinav International monthly referred journal of research in Management and Technology, 5(8),33-36

4. Sarode, R. M. (2015). Future of E-Commerce in India Challenges \& Opportunities. International Journal of Applied Research, 1(12), 646650 .

5. Saxena, P. (2015). E-Commerce and its impact on Indian society. International Journal of Management and Computer Innovations, Vol. 3, $520-522$.

\section{Websites}

- $\quad$ https://www.ibef.org/industry/ecommerce.aspx\#

- https://www.ibef.org/download/E-Commerce-December-2019.pdf

- https://retail.economictimes.indiatimes.com/news/e-commerce/e-tailing/trends-to-watch-out-for-in-the-ecommerce-sector-2020/73422007

- https://www.perceptionsystem.com/blog/5-major-challenges-faced-ecommerce-businesses-india/

- https://www.businesstoday.in/current/economy-politics/online-shopping-frauds-jump-6-fold-in-over-2years/story/391975.html

- https://creadits.com/blog/6-obstacles-to-ecommerce-success-need-addressing-2019/

- https://vwo.com/blog/trust-in-ecommerce/?utm_campaign=tof_ugc

- https://www.insightssuccess.in/understanding-e-commerce-in-india/ 